\title{
Fuzzy AHP Based Optimal Design Building-Attached Photovoltaic System for Academic Campus
}

\author{
Mega Ardisa Hapsari and Subiyanto Subiyanto \\ Department of Electrical Engineering, Universitas Negeri Semarang, Semarang 50229, Indonesia \\ Correspondence should be addressed to Subiyanto Subiyanto; subiyanto@mail.unnes.ac.id
}

Received 11 September 2019; Revised 21 November 2019; Accepted 3 December 2019; Published 16 January 2020

Academic Editor: Manuel Fuentes Conde

Copyright (c) 2020 Mega Ardisa Hapsari and Subiyanto Subiyanto. This is an open access article distributed under the Creative Commons Attribution License, which permits unrestricted use, distribution, and reproduction in any medium, provided the original work is properly cited.

\begin{abstract}
Several algorithms have been developed for building-attached photovoltaic system (BAPV) planning in educational institute based on PV capacity. Fewer studies on optimization algorithms for BAPV system planing on campus have been reported which considers a technoeconomic assessment. Therefore, a well-known robust algorithm is used as an optimization technique of BAPV system and considers technoeconomic assessment on campus. This paper presents a combination of analytical hierarchy process (AHP) with fuzzy theory (fuzzy AHP) for selecting a suitable and optimal design of BAPV system on academic campus. The BAPV system design is based on roof area and load profile at the project site. Five BAPV systems have been designed using five different types of PV. The design was comprehensively assessed by experts through a questionnaire with pairwise comparison model. Fuzzy AHP used to consider the qualitative and quantitative assessments that can affect the selection process. The comprehensive assessment in criteria consists of sizing systems, technical, economic, and environmental perspectives as criteria. The perspective is divided into 13 subcriteria. The results show degree of importance from the criteria-based fuzzy AHP as follows: technical > economic > environment > sizing system. Based on the assessment of criteria and subcriteria, design with monocrystalline is most suitable and polycrystalline as the least suitable design for BAPV system connected to grid and battery energy storage system in case study.
\end{abstract}

\section{Introduction}

Global primary energy consumption increased by $2.2 \%$ in 2017 [1]. Natural gas still dominates as global primary energy [2]. Fossil fuel as an conventional energy resource was decreased and has a large impact to the environment. The electrical demand was dominated by fossil fuel generation supply that induces high cost and increased carbon dioxide emissions [3]. Renewable and sustainable energy technologies are at the forefront of environmental concerns, independence in energy, and solutions for high cost of fossil fuels [4]. Renewable energy offers great potential for reducing greenhouse gas (GHG) emissions and other environmental impacts from electricity production. In global power plants, the uses of renewable energy plants increased from $7.4 \%$ to $8.4 \%$ [1]. Renewable energy resources grew by $17 \%$, contributed to almost half of the growth of electricity generation (49\%) [1]. For example, solar photovoltaic (PV) is one of renewable energy resources that can replace fossil fuel resources. It can also be implemented in a distributed generation system where electricity plant and consumer are in the same location. Until 2016, more than $310 \mathrm{GW}$ of electricity worldwide was generated by photovoltaic technology [5].

Building-attached photovoltaic (BAPV) and buildingintegrated photovoltaic (BIPV) are two of the innovative ways to implement solar photovoltaic technology. Several countries have been implemented the BIPV and BAPV systems. Germany adopted the "Rooftop Solar Electricity Program" law to encourage the development of BAPV. Japan subsidized the cost of installing PV system in residential buildings. PV systems in American and California increased to $62 \mathrm{MW}$ and $36.5 \mathrm{MW}$ in 2004 [6]. In [7], study has given a comparative assessment of the BIPV vs. BAPV project in Bangalore, India. That study provided results BIPV system is not the best configuration in overall PV performance. In [8], it compares BAPV and BIPV systems with various PV 


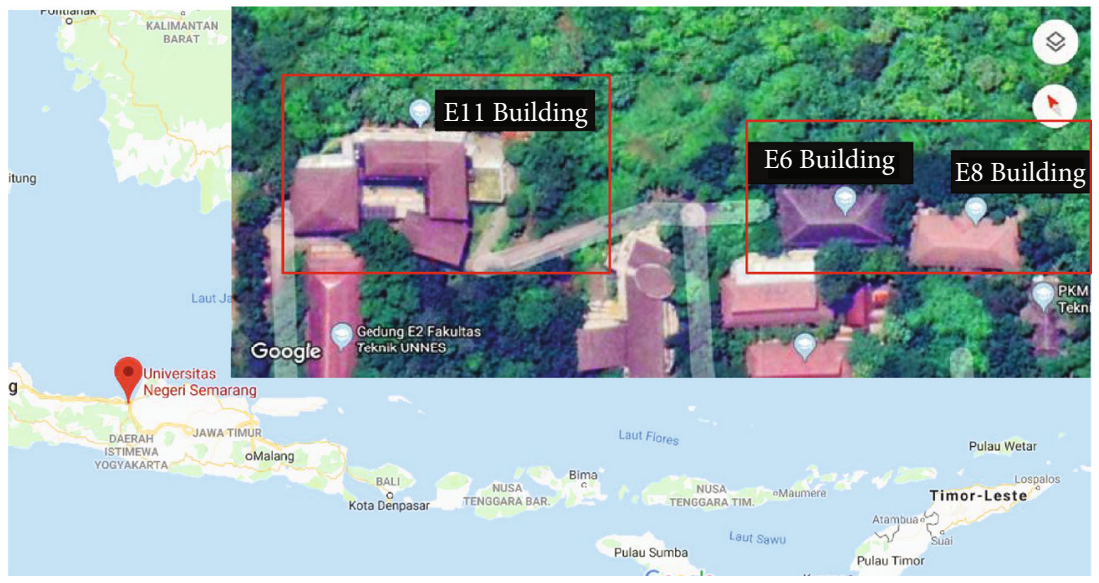

Figure 1: Detail location and building of the project site experiment.

technologies in countries with tropical climates. That study proved the BAPV system has better performance than the BIPV system. It means the BAPV system is relative more feasible to be implemented than BIPV system. BAPV system can be installed in any kind of building. Not only for residential buildings but also the BAPV and BIPV systems can be implemented or planned for campus academics [9-13]. PV project for the academic campus is a useful strategy. Academic buildings have many advantages to decrease electricity costs and research opportunities and increase the energy mix on campus. PV systems also support green energy on campus and reduce carbon dioxide $[9,14]$.

Although the BAPV system is better than the BIPV system, not all BAPV systems are feasible to be implemented. There are many factors that can affect BAPV system performance. Optimization of design, PV type, arrangement array of PV (in a roof or in facade), initial cost of system, cost of operation, and maintenance can affect the performance [8]. Geographical condition in every country also determines the performance of system. In China, the best PV type is HIT [15]. a-Si PV type has the best performance to be applied in Brunei Darussalam and Bhopal, India [16]. In Singapore, monocrystalline PV has the lowest degradation of performance that is $-0.8 \%$ per year [17]. In Malaysia, the best PV type is CdTe [8].

Thus, a technoeconomic assessment is needed to determine the feasibility of PV system performance. In [18], a rooftop PV system with grid and batteries in China was conducted. Technical, economic, and environmental aspect evaluation shows the system has good feasibility with cost of energy (COE) \$0.073/kWh. In [19], it reviewed the economic factors of PV system for residential buildings in Khartoum, Sudan. The $12 \mathrm{kWp}$ PV system in Khartoum, Sudan, is relatively feasible because it has an COE of $\$ 0.051 / \mathrm{kWh}$ with a local electricity cost is $\$ 0.055 / \mathrm{kWh}$.

One consideration in implementation BAPV system is required a priority factor chosen. Multicriteria decisionmaking (MCDM) algorithm can be used to determine the main priorities of several existing considerations. MCDM is widely used in several cases related to photovoltaic technology. In previous works, MCDM has been used to select the suitable PV modules [20], used to investigate the most poten- tial location for PV plants $[21,22]$, select best PV technologies [23], determine the most optimal renewable energy scenario [21], and prioritize PV/T technologies [24].

Based on research studies that have perspectives, the feasibility of a BAPV system is determined by an assessment of technoeconomic factors. However, fewer studies about optimization algorithms for BAPV system planning on campus consider a technoeconomic assessment. Therefore, optimization technique with a well-known robust algorithm is used to get the best BAPV system design and considers technoeconomic assessment on campus. In this paper, combination of analytic hierarchy process with fuzzy theory is presented to choose the optimal and suitable BAPV system design in academic campus. Parameter assessment consists of a sizing system factor, technical factor, economic factor, and environment factor. Five existing PV technologies are used as an alternative design. The system design is simulated using $\mathrm{PV} *$ Sol Premium to get the value of assessment. Evaluations are obtained with qualitative and quantitative opinions from experts in BAPV system planning and assessment. The evaluation resulted in one of the most optimal BAPV design choices to be applied at the project site.

\section{Profile of the Project Site}

Department of Electrical Engineering in Universitas Negeri Semarang is located in Sekaran, Gunung Pati, Semarang City, with the tropical climate in coordinates $7.05^{\circ}$ south latitude, $110.40^{\circ}$ east longitude, and an altitude of $187 \mathrm{~m}$ above sea level [25]. Three buildings as project case are, namely, E11, E6, and E8 Buildings (Figure 1). Building inspections have been carried out in the roof area, roof type, roof pitch, and orientation of roof [9]. Total available roof areas in E11 Building and E6+E8 Buildings are $540 \mathrm{~m}^{2}$ and $504 \mathrm{~m}^{2}$. E11 Building is divided into 4 roof areas with a total available area of $1,060.44 \mathrm{~m}^{2}$. Roofs tilt in all buildings are $35^{\circ}$, except the flat roof in south-oriented of E11 Building is $16^{\circ}$ [26]. Electricity demand at E11 Building is $179 \mathrm{kWh} /$ day and E6+E8 Buildings is $67.5 \mathrm{kWh} /$ day [27]. Detailed hourly energy demand in each building has been predicted with $\mathrm{PV} *$ Sol Premium and shown in Figure 2. Daily irradiation and 


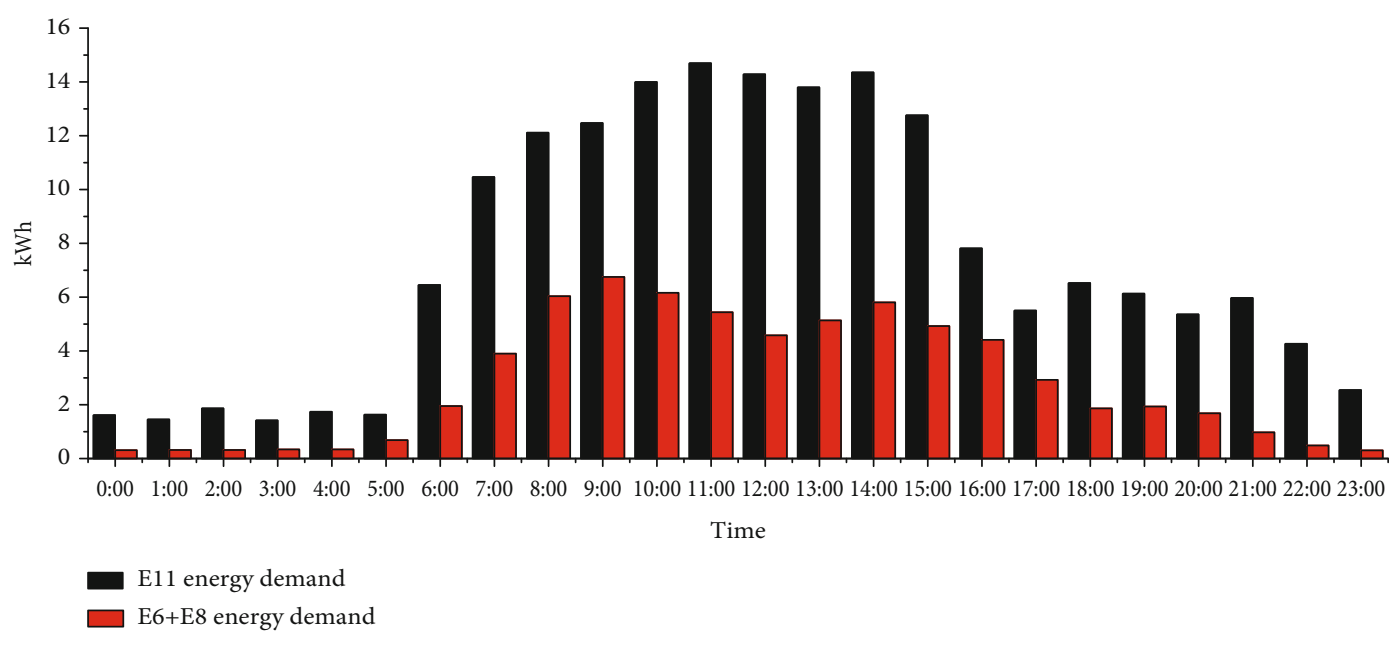

FIgure 2: Predicted hourly energy demand in project site with PV $*$ Sol Premium.

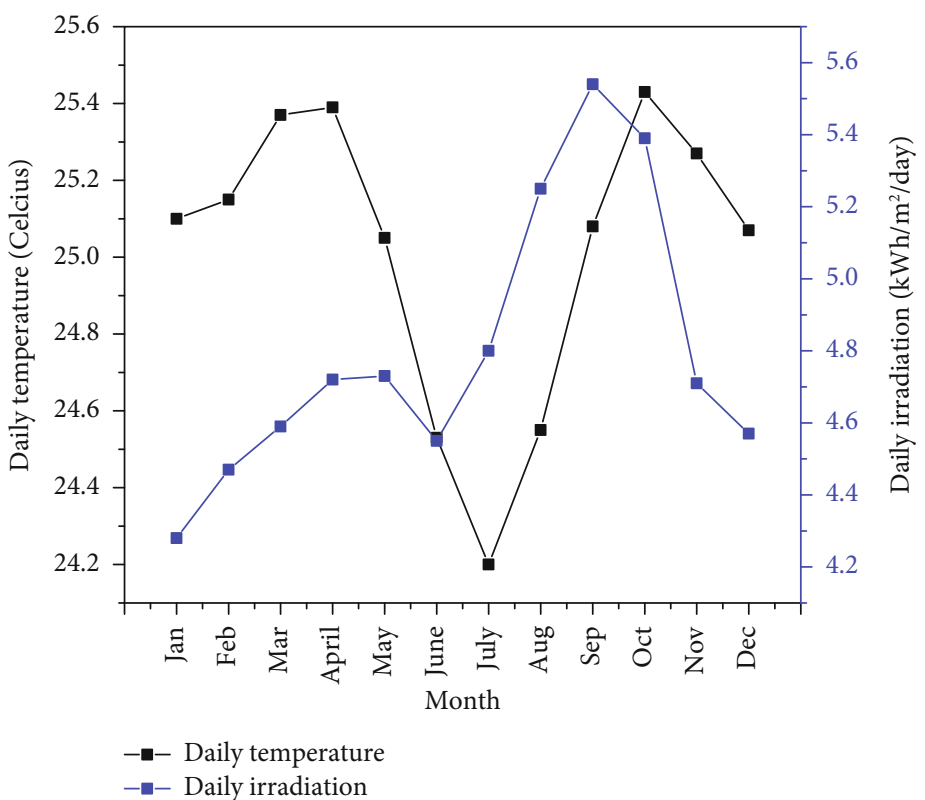

Figure 3: Daily irradiation and temperature in the project site.

temperature in this project site-based Meteonorm are shown in Figure 3.

\section{Design of BAPV System}

The BAPV system was designed to reducing energy used from grid. This paper shows 2 scenarios of BAPV system. The first scenario is $73.5 \mathrm{~kW}$ capacity of BAPV system connected to grid and battery energy storage system (BESS) for E11. BESS was added to E11 Building because it has high productivity in college activities. In addition, BESS can reduce high peak demand and improve the quality of the power system. The optimization of the BAPV system can be increased using the appropriate BESS capacity [28]. The second scenario is $31.5 \mathrm{kWp}$ capacity of BAPV system with a grid only for E6+E8 Buildings. The BAPV system for Buildings E6 and E8 was combined because the building was integrated. System capacity is based on the roof area available in each building and PV requires alternatives [29]. Scheme of BAPV systems is shown in Figures 4 and 5.

There are five BAPV designs for each scenario with five different PV types from German manufacturing, which are heterojunction PV (HIT), cadmium telluride PV (CdTe), copper indium selenium PV (CIS), monocrystalline PV (m-Si), and polycrystalline PV (p-Si). PV was chosen because it has high efficiency of $15-20 \%$. Table 1 shows the details of PV type used in this design BAPV system.

Sizing inverter capacity is based on the BAPV system capacity. BAPV system is connected to the grid, so a gridtie inverter type is chosen because the inverter type can adjust 


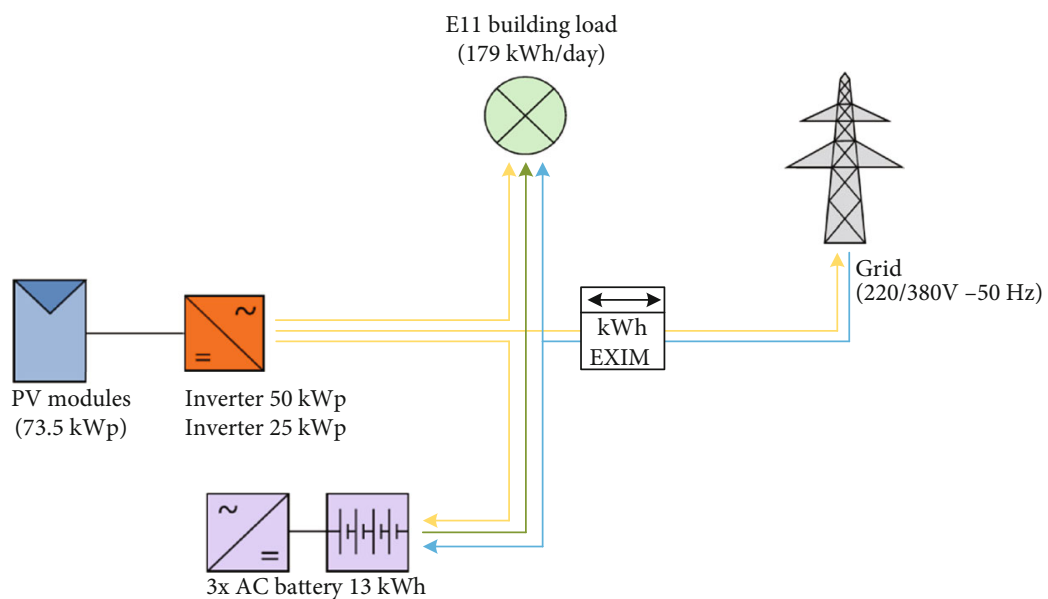

FIgURE 4: Scheme of BAPV connected to grid and BESS for E11 Building as scenario 1.

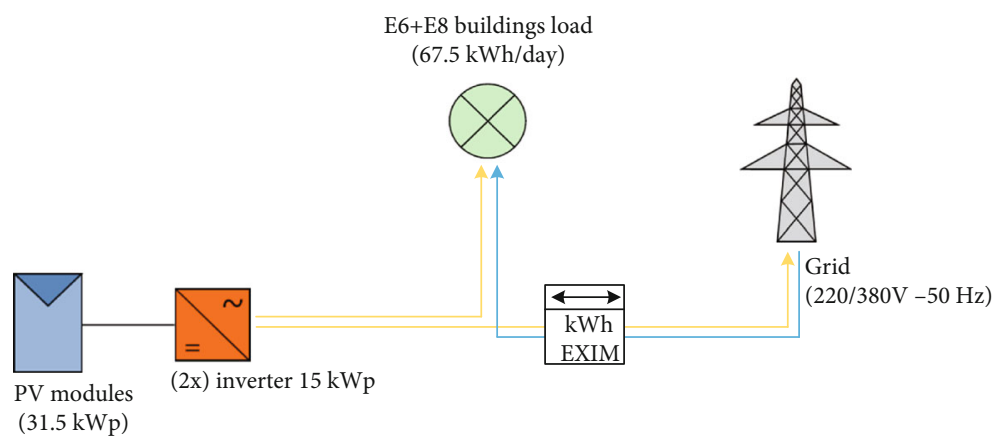

FIgURE 5: Scheme of BAPV connected to the grid for E6+E8 Buildings as scenario 2.

TABle 1: Modules PV used of design BAPV system.

\begin{tabular}{|c|c|c|c|c|c|}
\hline & Design 1 & Design 2 & Design 3 & Design 4 & Design 5 \\
\hline PV type & HIT & $\mathrm{CdTe}$ & CIS & $\mathrm{m}-\mathrm{Si}$ & $\mathrm{p}-\mathrm{Si}$ \\
\hline Nominal power $(\mathrm{Wp})$ & 250 & 420 & 175 & 350 & 250 \\
\hline Weight of PV (kgs) & 15 & 36 & 20 & 18.6 & 19 \\
\hline Efficiency & $19.8 \%$ & $18 \%$ & $14.2 \%$ & $20.6 \%$ & $15.37 \%$ \\
\hline Temperature coefficient $\left(\% /{ }^{\circ} \mathrm{C}\right)$ & -0.28 & -0.32 & -0.31 & -0.25 & -0.40 \\
\hline
\end{tabular}

the voltage and frequency of the grid [9]. AC battery type was chosen as BESS to cover 15\% of energy demand. Price of the main components used is shown in Table 2. The price is taken from several online market places.

\section{Fuzzy AHP Based Component Selection of BAPV System Design}

The development of BAPV system is supported by various $\mathrm{PV}$ types. Five types of PV that are chosen in Table 1 is needed to be selected to obtain the most optimal and suitable for BAPV system design. In this paper, HIT PV (represented in design 1), CdTe PV (represented in design 2), CIS PV (represented in design 3), m-Si PV (represented in design
TABLE 2: Cosf of the designed BAPV system main components.

\begin{tabular}{lc}
\hline Component & Unit price \\
\hline Module m-Si & $\$ 320$ \\
Module p-Si & $\$ 243$ \\
Module CIS & $\$ 162$ \\
Module CdTe & $\$ 445$ \\
Module HIT & $\$ 239$ \\
Inverter 50 kWp & $\$ 5,265$ \\
Inverter 25 kWp & $\$ 3,185$ \\
Inverter $15 \mathrm{kWp}$ & $\$ 2,939$ \\
AC battery $13 \mathrm{kWh}$ & $\$ 8,750$ \\
\hline
\end{tabular}




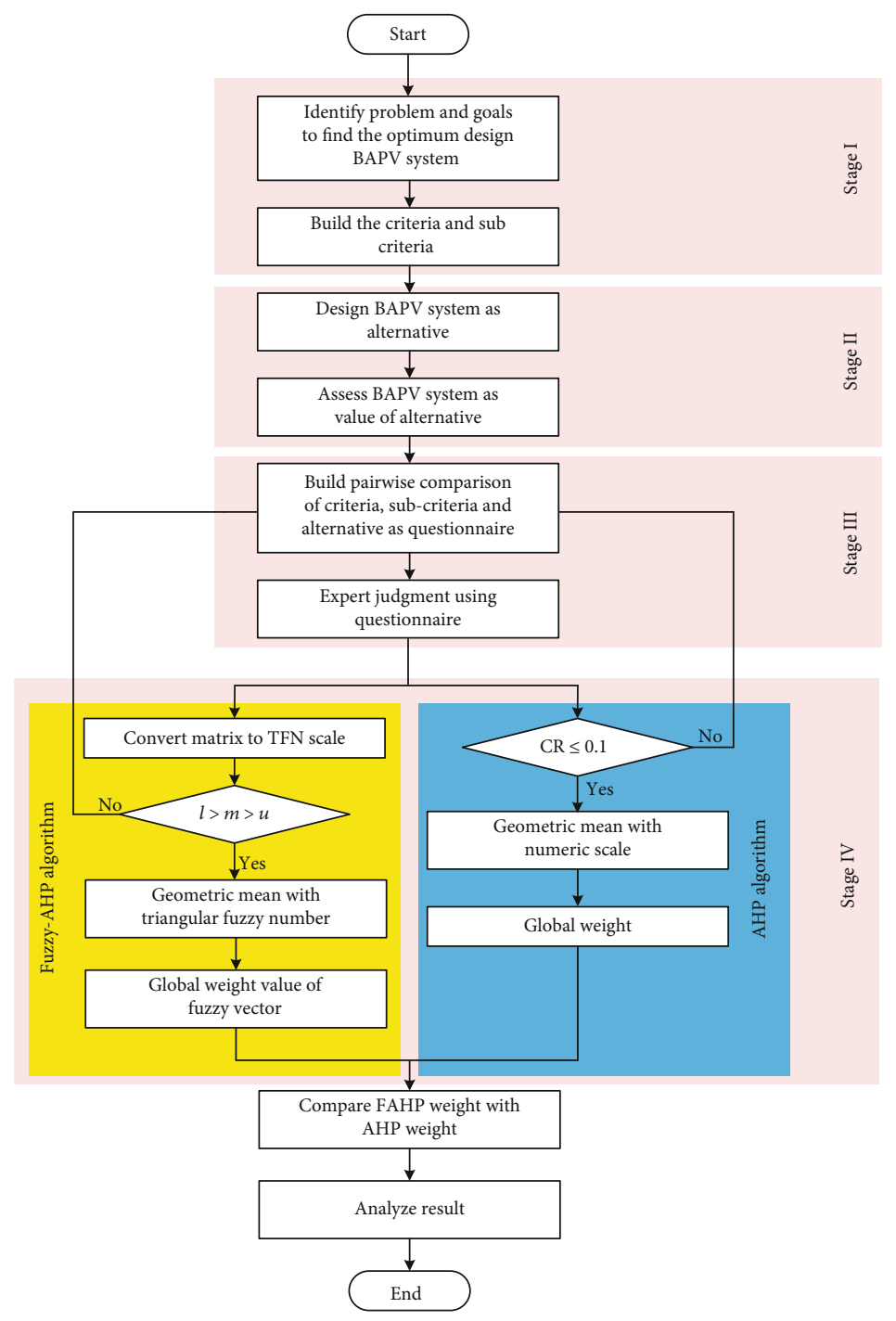

Figure 6: Hierarchy for fuzzy AHP in BAPV system.

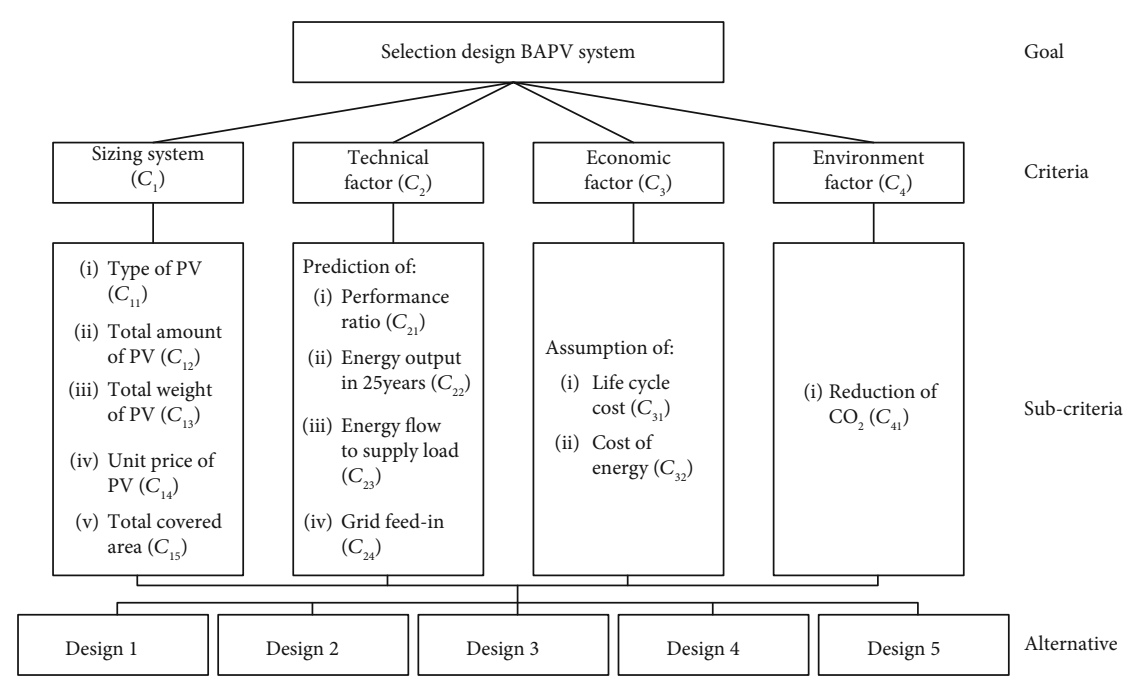

FIGURE 7: The framework of fuzzy AHP in the proposed project. 


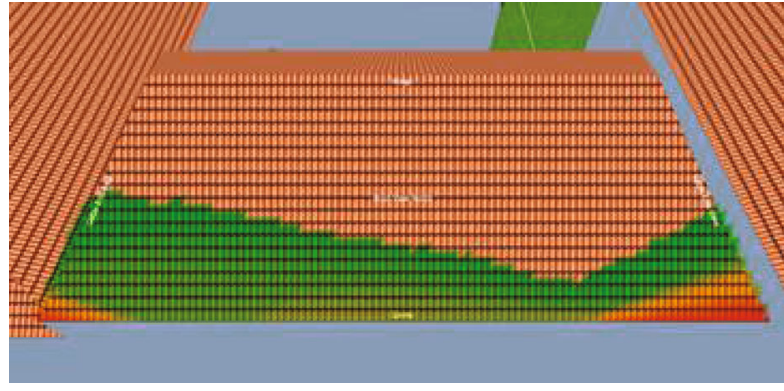

(a)

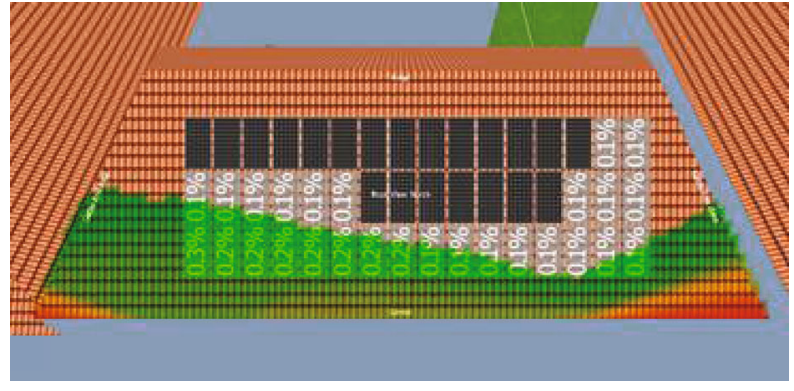

(b)

Figure 8: Examples of the shading analyses with PhotoPlan 3D in PV*Sol Premium: (a) without PV and (b) with PV.

4), and p-Si PV (represented in design 5) are selected as object experiment (Figure 6). Evaluation of parameter assessment on BAPV systems based on fuzzy AHP has been carried out by four experts in PV planning and assessment. For more comprehensive in prioritizing the BAPV system designs, several assessment perspectives are considered with relevant references $[8,15]$.

Fuzzy AHP algorithm is divided into 4 main stages. The first stage begins by constructing the hierarchy including goal, criteria, and subcriteria. Criteria are built from the perspective of sizing system, technical, economic, and environment. Subcriteria is built from detailed assessment of each criteria. The second stage is designing and assessing five alternative designs of BAPV systems for project experiment. The third stage is making an assessment of the hierarchy by an expert with questionnaire. An expert was needed to give opinion about comparison the criteria, subcriteria, and alternative using numeric scale. After getting the experts' opinion, the last stage is calculating the experts' opinion using fuzzy AHP algorithm and find the best option. The detailed explanation of the main stage algorithm is shown as a flowchart in Figure 7.

\section{Stage 1. Construct the hierarchy}

Criteria and subcriteria were built with different level as a hierarchical model to evaluate the alternative and achieve the goal [30]. Hierarchy of fuzzy AHP is shown in Figure 6. Sizing system, economic, technical, and environmental factors are the main criteria to get the most optimal BAPV system design in this project. Detail of criteria and subcriteria was explained in Sections 4.1-4.4.

4.1. Criteria of Sizing. Each alternative design of BAPV system uses a different type and nominal rating of PV, so sizing each design has difference. Each BAPV system design has own advantages and different performances according to installation conditions and location [8].

Detailed assessment of sizing system such as type of PV, amount of PV, weight of PV, covered area with PV, and unit price of PV is used as subcriteria. Different types of PV can affect the amount of PV that needs to be used and the total weight of the PV. For example, alternative design 1 uses a PV-type HIT $250 \mathrm{Wp}$; it takes 294 modules to get a capacity
TABLe 3: Detail initial investment cost of BAPV system design 1 in scenario 1.

\begin{tabular}{lc}
\hline Cost of PV & $\$ 70,266$ \\
Cost of inverter & $\$ 8,450$ \\
Cost of battery & $\$ 26,250$ \\
Cost of installation & $\$ 10,496$ \\
Cost of cabling & $\$ 15,745$ \\
Cost of shipping & $\$ 79,307$ \\
Total initial investment cost & $\$ 210,515$ \\
\hline
\end{tabular}

of $73.5 \mathrm{kWp}$. Different from alternative design 2 that uses PV-type CIS $175 \mathrm{Wp}$, it needed 420 modules to get the same capacity with design 1 . Each design alternative has a different total PV weight and covered area by PV, depending on the type of the PV used.

4.2. Criteria of Technical Assessment. The technical assessment is affected by the performance of BAPV system in real conditions. In this paper, the BAPV system design was simulated in location of project site using software PV $*$ Sol Premium (R10 version with student license). PV $*$ Sol Premium is predicting accurately the performance of BAPV system design with $3 \mathrm{D}$ visualization. The simulation is carried out in 3 dimensions to calculate shading, geographical condition, orientation, and tilt of the roof at the project site in more detail $[13,31,32]$. BAPV design assuming the system is connected to the grid without failures. Some output from PV* Sol are used as a parameter in subcriteria of technical such as performance ratio, yearly energy spent to the load, total energy output during the system lifetime, and grid feed-in. An example of rooftop shading using HIT PV is shown in Figure 8 .

4.3. Criteria of Economic Assessment. Initial investment cost, life cycle cost (LCC), and cost of energy (COE) are calculated as subcriteria of economic. Initial investment cost is calculated with summing the cost of components system (PV, battery, inverter, balance of system (BOS) [33]), cost of shipping, cost of installation, and cost of cabling. Detailed cost of component is shown in Table 2. Shipping cost is assumed 
TABLE 4: Detail LCC of BAPV system design 1 in scenario 1.

\begin{tabular}{|c|c|c|c|c|c|c|}
\hline \multirow{2}{*}{ Years } & \multirow{2}{*}{ Discount factor } & \multirow{2}{*}{ Initial investment cost } & \multicolumn{2}{|c|}{ Cost of replacement } & \multirow{2}{*}{ Cost of O\&M } & \multirow{2}{*}{ Total } \\
\hline & & & Battery & Inverter & & \\
\hline 0 & 1.0000 & $\$ 210,515$ & & & & $\$ 210,515$ \\
\hline 1 & 0.9434 & & & & $\$ 3,972$ & $\$ 3,972$ \\
\hline 2 & 0.8900 & & & & $\$ 3,747$ & $\$ 3,747$ \\
\hline 3 & 0.8396 & & & & $\$ 3,535$ & $\$ 3,535$ \\
\hline 4 & 0.7921 & & & & $\$ 3,335$ & $\$ 3,335$ \\
\hline 5 & 0.7473 & & & $\$ 6,314$ & & $\$ 6,314$ \\
\hline 6 & 0.7050 & & & & $\$ 2,968$ & $\$ 2,968$ \\
\hline 7 & 0.6651 & & & & $\$ 2,800$ & $\$ 2,800$ \\
\hline 8 & 0.6274 & & & & $\$ 2,642$ & $\$ 2,642$ \\
\hline 9 & 0.5919 & & & & $\$ 2,492$ & $\$ 2,492$ \\
\hline 10 & 0.5584 & & $\$ 14,657$ & $\$ 4,718$ & & $\$ 19,376$ \\
\hline 11 & 0.5268 & & & & $\$ 2,218$ & $\$ 2,218$ \\
\hline 12 & 0.4970 & & & & $\$ 2,092$ & $\$ 2,092$ \\
\hline 13 & 0.4688 & & & & $\$ 1,974$ & $\$ 1,974$ \\
\hline 14 & 0.4423 & & & & $\$ 1,862$ & $\$ 1,862$ \\
\hline 15 & 0.4173 & & & $\$ 3,526$ & & $\$ 3,526$ \\
\hline 16 & 0.3936 & & & & $\$ 1,657$ & $\$ 1,657$ \\
\hline 17 & 0.3714 & & & & $\$ 1,564$ & $\$ 1,564$ \\
\hline 18 & 0.3503 & & & & $\$ 1,475$ & $\$ 1,475$ \\
\hline 19 & 0.3305 & & & & $\$ 1,392$ & $\$ 1,392$ \\
\hline 20 & 0.3118 & & $\$ 8,184$ & $\$ 2,635$ & & $\$ 10,820$ \\
\hline 21 & 0.2942 & & & & $\$ 1,238$ & $\$ 1,238$ \\
\hline 22 & 0.2775 & & & & $\$ 1,168$ & $\$ 1,168$ \\
\hline 23 & 0.2618 & & & & $\$ 1,102$ & $\$ 1,102$ \\
\hline 24 & 0.2470 & & & & $\$ 1,040$ & $\$ 1,040$ \\
\hline \multirow[t]{2}{*}{25} & 0.2330 & & & & $\$ 981$ & $\$ 981$ \\
\hline & & $\$ 210,515$ & $\$ 22,843$ & $\$ 17,193$ & $\$ 45,255$ & $\$ 295,806$ \\
\hline
\end{tabular}

using FedEx expedition to Semarang City, Indonesia [34]. Installation costs are assumed at $10 \%$ of PV+inverter+battery costs [35] and cabling costs are assumed at 15\% of component costs. Table 3 shows detail initial investment cost of design 1 in scenario 1 .

LCC is the total cost of investing in the BAPV system during the lifetime (25 years). LCC is calculated with summing the cost of initial investment, cost of operation and maintenance (O\&M), and cost of replacement components. Cost of O\&M is assumed at $2 \%$ of the PV cost in each year multiplied by the discount factor $(R)$ value for a year [35-37]. The interest rate in calculating the discount factor follows the value of Bank Indonesia interest rates in May 2019 of $6.0 \%$ [38]. The cost of replacement components is calculated based on the lifetime of each component. In this plan, the photovoltaic module used has a 25-year warranty. So, there is no need of replacement of PV modules during BAPV system lifetime. The inverter has a lifetime of 5 years and makes a 5-time replacement. BESS has a lifetime of 10 years, so there will be a 2-time replacement. Table 4 shows detailed LCC of design BAPV system with HIT PV.
COE is the cost of electrical energy produced per kWh by a BAPV system during the lifetime. The energy produced in the system lifetime is affected by the degradation of PV $(r)$. COE is calculated as follows in Equation (4) [39]:

$$
\mathrm{COE}=\frac{\mathrm{LCC}}{\sum_{m=1}^{n}\left(E_{m} *(1-r)\right)},
$$

where $E_{m}$ is energy output in $m$-year. Then, $r$ is degradation of PV.

4.4. Criteria of Environment Assessment. Reducing $\mathrm{CO}_{2}$ and improving human living standard is one of the advantages of utilizing rooftop for BAPV system [40]. The emission of $\mathrm{CO}_{2}$ reduction is related to the amount of energy that can be produced by the BAPV system.

Stage 2. Construct the alternative

Five alternatives of BAPV system were designed to be chosen using the fuzzy AHP method. Evaluation criteria of the five BAPV system designs have been carried out. Details 


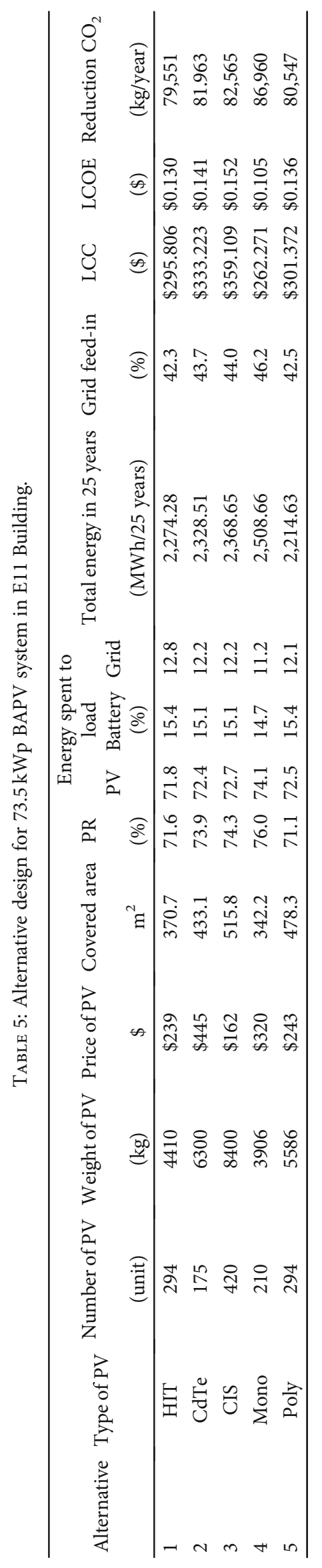




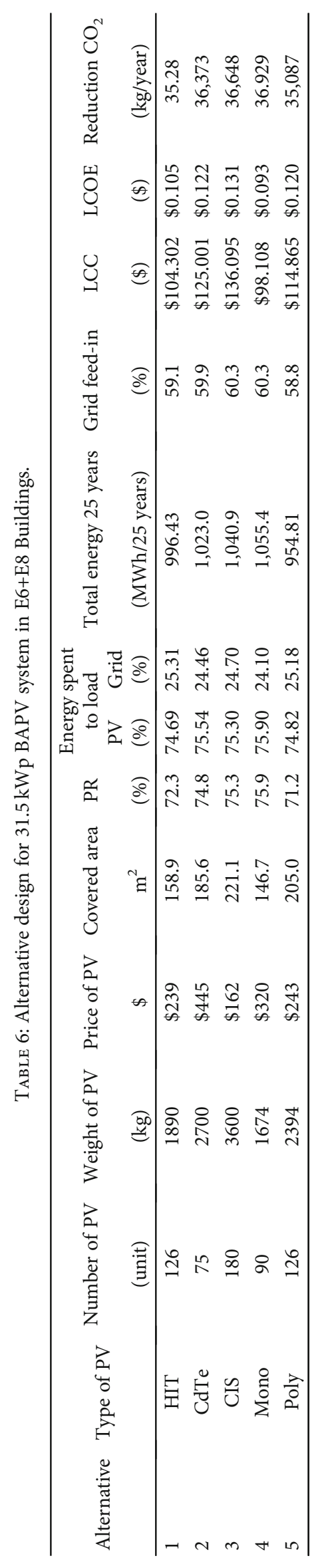


TABLE 7: Comparison of criteria in a numerical scale of experts.

\begin{tabular}{|c|c|c|c|c|c|}
\hline & Criteria & Sizing & Technical & Economic & Environment \\
\hline \multirow{4}{*}{ Expert 1} & Sizing & 1 & $1 / 7$ & 1 & 5 \\
\hline & Technical & 7 & 1 & 5 & 7 \\
\hline & Economic & 1 & $1 / 5$ & 1 & 9 \\
\hline & Environment & $1 / 5$ & $1 / 7$ & $1 / 9$ & 1 \\
\hline \multirow{4}{*}{ Expert 2} & Sizing & 1 & $1 / 5$ & $1 / 6$ & $1 / 5$ \\
\hline & Technical & 5 & 1 & 2 & $1 / 2$ \\
\hline & Economic & 6 & $1 / 2$ & 1 & 2 \\
\hline & Environment & 5 & 2 & $1 / 2$ & 1 \\
\hline \multirow{4}{*}{ Expert 3} & Sizing & 1 & $1 / 5$ & $1 / 7$ & $1 / 9$ \\
\hline & Technical & 5 & 1 & $1 / 4$ & $1 / 7$ \\
\hline & Economic & 7 & 4 & 1 & $1 / 5$ \\
\hline & Environment & 9 & 7 & 5 & 1 \\
\hline \multirow{4}{*}{ Expert 4} & Sizing & 1 & 3 & 5 & 7 \\
\hline & Technical & $1 / 3$ & 1 & 3 & 5 \\
\hline & Economic & $1 / 5$ & $1 / 3$ & 1 & 3 \\
\hline & Environment & $1 / 7$ & $1 / 5$ & $1 / 3$ & 1 \\
\hline
\end{tabular}

TABle 8: Triangular fuzzy number.

\begin{tabular}{lccc}
\hline Linguistic variable & Numeric scale & TFN scale $(l, m, u)$ & Reciprocal $(l, m, u)$ \\
\hline Equally strong & 1 & $(1,1,1)$ & $(1,1,1)$ \\
Moderately strong & 3 & $(1,3 / 2,2)$ & $(1 / 2,2 / 3,1)$ \\
Strong & 5 & $(2,5 / 2,3)$ & $(1 / 3,2 / 5,1 / 2)$ \\
Very strong & 7 & $(3,7 / 2,4)$ & $(1 / 4,2 / 7,1 / 3)$ \\
Extremely strong & 9 & $(4,4 / 5,5)$ & $(2 / 9,2 / 9,1 / 4)$ \\
Intermediate & $2,4,6,8$ & $(1 / 2,1,3 / 2) ;(3 / 2,2,5 / 2) ;(5 / 2,3,7 / 2) ;(7 / 2,4,9 / 2)$ & $(2 / 3,1,2) ;(2 / 5,1 / 2,2 / 3) ;(2 / 7,1 / 3,2 / 5) ;$ \\
& & $(2 / 9,1 / 4,2 / 7)$ \\
\hline
\end{tabular}

and assessments of five BAPV system designs for scenario 1 and scenario 2 are shown in Tables 5 and 6 .

\section{Stage 3. Expert opinion}

The fuzzy AHP algorithm processes the matrix derived from a questionnaire with pairwise comparison model. The questionnaire is filled with opinion from the experts. The questionnaire was made through Google Form and sent via email to the experts. This research involves 4 experts that were selected from related fields. The assessment of the four experts involved in this research has been able to determine the optimal and feasible system design.

Stage 4. Fuzzy AHP as decision-making of design BAPV system

Fuzzy AHP is the development of AHP using triangular fuzzy number (TFN) of fuzzy theory. Research in [41] shows combining AHP with fuzzy theory can focus on relative importance in evaluation criteria than the logic of human thinking. The fuzzy AHP method can help the decisionmaker to make a realistic and flexible decision based on the criteria and alternatives [42]. In this subsection, fuzzy AHP was developed to find the goal. The steps used in this method are described as follows $[43,44]$ :

Step 1. Build the pairwise comparison matrix for all criteria, subcriteria, and alternative

After the assessment from experts, a pairwise comparison matrix was made. The matrix must be made consistently by experts so it can be analyzing properly. Matrix of pairwise comparisons is made with Equation (2) [43]. An example of pairwise comparison of criteria is shown in Table 7.

$$
a_{i j}=\frac{w_{i}}{w_{j}}, \quad \text { where } i, j=1,2, \cdots, n \text {. }
$$

$W_{i}$ is weight for the $i$-criteria and $a_{i j}$ is the ratio of the weight for $i$-criteria and $j$-criteria. General matrix of pairwise comparison is shown in Equation (3) [42]: 
TABLE 9: Matrix geometric mean of criteria weight.

\begin{tabular}{lcccccccccccc}
\hline \multirow{2}{*}{ Criteria } & \multicolumn{3}{c}{ Sizing } & \multicolumn{4}{c}{ Technical } & \multicolumn{3}{c}{ Economic } & \multicolumn{3}{c}{ Environment } \\
& $\mathrm{l}$ & $\mathrm{m}$ & $\mathrm{u}$ & $\mathrm{l}$ & $\mathrm{m}$ & $\mathrm{u}$ & $\mathrm{l}$ & $\mathrm{m}$ & $\mathrm{u}$ & $\mathrm{l}$ & $\mathrm{u}$ \\
\hline Sizing & 1.00 & 1.00 & 1.00 & 0.48 & 0.62 & 0.82 & 0.52 & 0.75 & 0.99 & 0.77 & 0.96 & 1.19 \\
Technical & 1.22 & 1.61 & 2.08 & 1.00 & 1.00 & 1.00 & 0.93 & 1.30 & 1.72 & 0.83 & 1.09 & 1.46 \\
Economic & 0.91 & 1.30 & 1.69 & 0.61 & 0.83 & 1.19 & 1.00 & 1.00 & 1.00 & 1.03 & 1.39 & 1.79 \\
Environment & 0.84 & 1.05 & 1.31 & 0.67 & 0.89 & 1.15 & 0.59 & 0.77 & 1.07 & 1.00 & 1.00 & 1.00 \\
\hline
\end{tabular}

$$
A=a_{i j} \cdot \frac{1}{a_{i j}^{T}}=\left[\begin{array}{cccc}
1 & a_{12} & \cdots & a_{1 n} \\
a_{21} & 1 & \cdots & a_{2 n} \\
\vdots & \vdots & \ddots & \vdots \\
a_{n 1} & a_{n 2} & \cdots & 1
\end{array}\right]
$$

Step 2. Convert into triangular fuzzy number (TFN)

The matrix in Step 2 was in numerical scale. To proceed to Step 2, convert the numerical scale to a TFN scale. The TFN scale is shown in Table 8.

Step 3. Geometric mean

Pairwise comparison matrix in TFN scale of all respondents needs to be combined with the calculation of fuzzy geometric mean as follows Equation (4). If the value of $l \leq m \leq u$, it means TFN matrix is consistent. Geometric means of pairwise comparison are shown in Table 9.

$$
\begin{aligned}
l_{i j} & =\left(\prod_{k=1}^{K} l_{i j k}\right)\left(\frac{1}{k}\right), \\
m_{i j} & =\left(\prod_{k=1}^{K} m_{i j k}\right)\left(\frac{1}{k}\right), \\
u_{i j} & =\left(\prod_{k=1}^{K} u_{i j k}\right)\left(\frac{1}{k}\right),
\end{aligned}
$$

where $l_{i j}, m_{i j}$, and $u_{i j}$ are the geometric means in TFN scale and $k$ is the number of experts.

Step 4. Calculated fuzzy synthesis value

Fuzzy synthesis value $\left(S_{i}\right)$ is defined as Equation (5). Fuzzy synthesis value of criteria is shown in Table 10.

$$
S_{i}=\sum_{j=1}^{m} M_{g i}^{j} *\left(\sum_{i=j}^{m} \sum_{i=1}^{n} M_{g i}^{j}\right)^{-1},
$$

where $S_{i}$ is fuzzy synthesis value. To obtain $\sum_{i=j}^{m} M_{g i}^{j}$ is summing the cell of $m$ in pairwise comparison matrix using Equation (6).

$$
\sum_{i=j}^{m} M_{g i}^{j}=\left(\sum_{i=j}^{m} l_{i}, \sum_{i=1}^{n} m_{i}, \sum_{i=j}^{m} u_{i}\right) .
$$

To obtain the value of $\left(\sum_{i=j}^{m} \sum_{i=1}^{n} M_{g i}^{j}\right)^{-1}$ is summing the fuzzy number from $M_{g i}^{j}$, where $j=1,2, \cdots, m$.
TABle 10: Matrix geometric mean of fuzzy synthesis value.

\begin{tabular}{lcccccc}
\hline \multirow{2}{*}{ Criteria } & \multicolumn{3}{c}{$\begin{array}{c}\text { Sum of row from } \\
\text { geometric mean }\end{array}$} & \multicolumn{3}{c}{ Fuzzy synthesis value } \\
& $l$ & $m$ & $u$ & $l$ & $m$ & $u$ \\
\hline Sizing & 2.770 & 3.325 & 3.997 & 0.135 & 0.201 & 0.298 \\
Technical & 3.986 & 4.995 & 6.257 & 0.195 & 0.302 & 0.466 \\
Economic & 3.559 & 4.513 & 5.671 & 0.174 & 0.273 & 0.423 \\
Environment & 3.101 & 3.708 & 4.532 & 0.152 & 0.224 & 0.338 \\
\hline
\end{tabular}

Table 11: Defuzzification of criteria.

\begin{tabular}{lcc}
\hline Criteria & $V^{\prime}$ & $D^{\prime}$ \\
\hline$V\left(C_{1} \geq C_{2}\right)$ & 0.50504 & \\
$V\left(C_{1} \geq C_{3}\right)$ & 0.63291 & 0.5050 \\
$V\left(C_{1} \geq C_{4}\right)$ & 0.86323 & \\
$V\left(C_{2} \geq C_{1}\right)$ & 1.43906 & \\
$V\left(C_{2} \geq C_{3}\right)$ & 1.11061 & 1.000 \\
$V\left(C_{2} \geq C_{4}\right)$ & 1.32828 & \\
$V\left(C_{3} \geq C_{1}\right)$ & 1.33354 & \\
$V\left(C_{3} \geq C_{2}\right)$ & 0.88669 & \\
$V\left(C_{3} \geq C_{3}\right)$ & 1.21884 & \\
$V\left(C_{4} \geq C_{1}\right)$ & 1.12937 & 0.6475 \\
$V\left(C_{4} \geq C_{2}\right)$ & 0.64750 & \\
$V\left(C_{4} \geq C_{3}\right)$ & 0.77086 & \\
\hline
\end{tabular}

TABLE 12: Value of fuzzy vector weight of criteria.

\begin{tabular}{lc}
\hline Criteria & $W^{\prime}$ \\
\hline Sizing & 0.16617 \\
Technical & 0.32903 \\
Economic & 0.29175 \\
Environment & 0.21305 \\
\hline
\end{tabular}

$$
\left(\sum_{i=j}^{m} \sum_{i=1}^{n} M_{g i}^{j}\right)^{-1}=\frac{1}{\sum_{i=1}^{n} u_{i}}, \frac{1}{\sum_{i=1}^{n} m_{i}}, \frac{1}{\sum_{i=1}^{n} l_{i}} .
$$

Step 5. Degree possibility of an element 
TABLE 13: Normalized of fuzzy vector weight of criteria and subcriteria for BAPV design scenario 1.

\begin{tabular}{lccc}
\hline Criteria & $W_{\text {Criteria }}$ & Subcriteria & $W_{\text {Subcriteria }}$ \\
\hline & & Type of PV $\left(C_{11}\right)$ & 0.2409 \\
& & Number of PV $\left(C_{12}\right)$ & 0.2340 \\
Sizing $\left(C_{1}\right)$ & 0.16617 & Weight of PV $\left(C_{13}\right)$ & 0.1650 \\
& & Unit price PV $\left(C_{14}\right)$ & 0.1872 \\
& & Covered area $\left(C_{15}\right)$ & 0.1729 \\
\hline & & Performance ratio $\left(C_{21}\right)$ & 0.3763 \\
Technical $\left(C_{2}\right)$ & 0.32903 & Energy spent to load $\left(C_{22}\right)$ & 0.2465 \\
& & Total energy in 25 years $\left(C_{23}\right)$ & 0.1967 \\
\hline Economic $\left(C_{3}\right)$ & & Grid feed-in $\left(C_{24}\right)$ & 0.1805 \\
\hline Environment $\left(C_{4}\right)$ & 0.29175 & Life cycle cost $\left(C_{31}\right)$ & 0.5000 \\
\hline
\end{tabular}

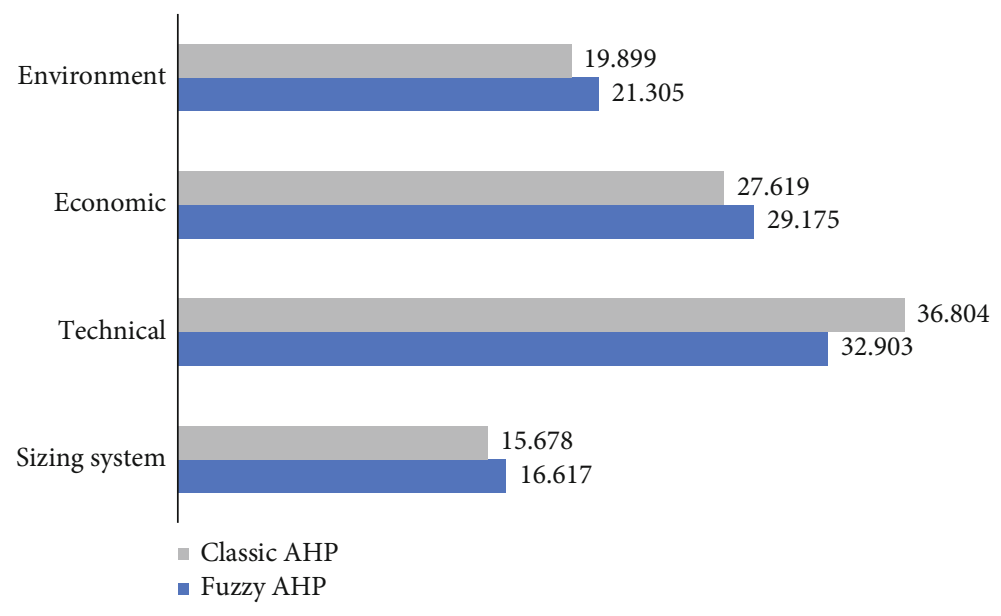

Figure 9: Priority weight of criteria.

Degree possibility $\left(v^{\prime}\right)$ is calculated according to the value of fuzzy synthesis, using Equation (8), and is shown in Table 11 .

$$
V\left(M_{2} \geq M_{1}\right)= \begin{cases}1, \text { if } m_{2} \geq m_{1}, & \text { if } l_{1} \geq u_{2}, \\ \frac{l_{1}-U_{2}}{\left(m_{2}-u_{2}\right)-\left(m_{1}-l_{1}\right)}, & \text { etc. }\end{cases}
$$

Step 6. Calculated fuzzy vector weight and defuzzification of ordinate value

After defuzzification, the value of fuzzy vector weight is obtained using Equation (9).

$$
W^{\prime}=\left(d^{\prime}\left(A_{1}\right), d^{\prime}\left(A_{2}\right), \cdots, d^{\prime}\left(A_{n}\right)\right)^{\mathrm{T}}
$$

where $A_{i}=1,2, \cdots, n$ is number of element criteria and $d^{\prime}\left(A_{1}\right)$ is obtained from $d^{\prime}\left(A_{1}\right)=\min V\left(S_{i} \geq S_{k}\right)$. Value of fuzzy vector weight of criteria is shown in Table 12.

Step 7. Normalized fuzzy vector weight

Normalized fuzzy vector weight is calculated using Equation (10).

$$
W=\left(d\left(A_{1}\right), d\left(A_{2}\right), \cdots, d\left(A_{n}\right)\right)^{\mathrm{T}},
$$

where $W$ is a nonfuzzy number. Normalized fuzzy vector of criteria and subcriteria is shown in Table 13.

Step 8. Global priority and ranking the alternatives

Global priority is calculated by multiplying the fuzzy vector weight of the criteria, subcriteria, and alternatives assessed. The rank of alternative is obtained after ordering the highest value of global priority as the first priority and smallest value as the last priority. 


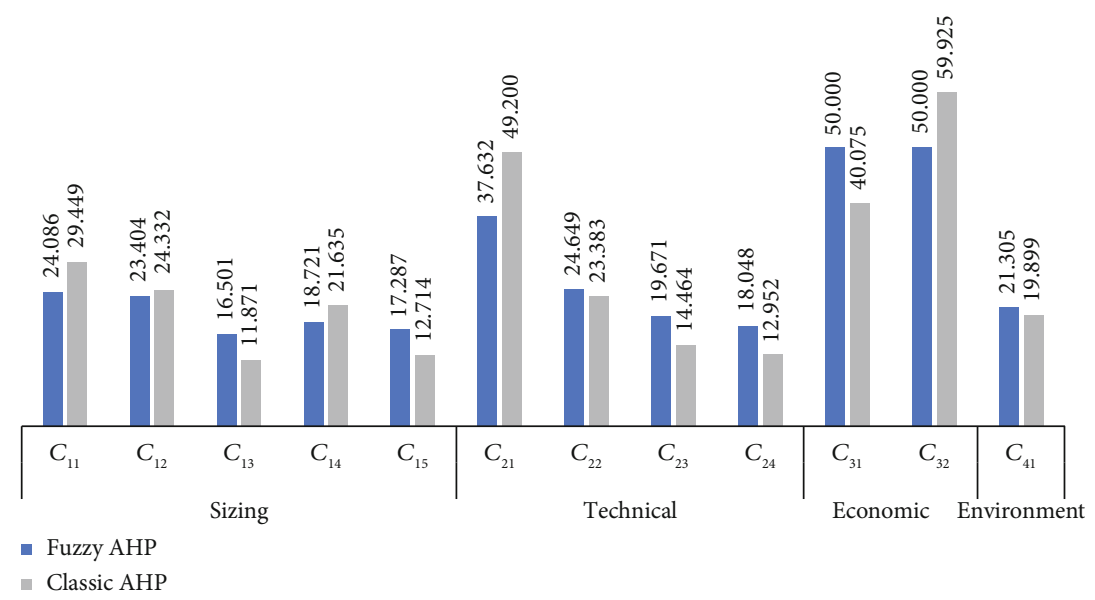

Figure 10: Priority weight of subcriteria.

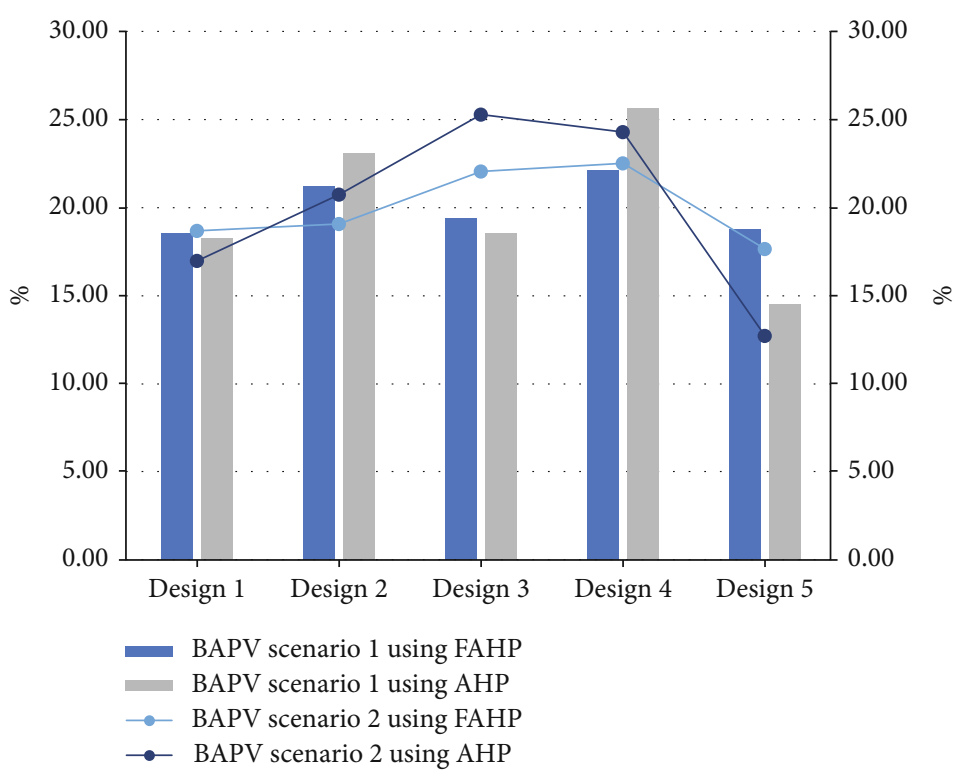

Figure 11: Priority weight of alternative.

\section{Comprehensive Evaluation of Design BAPV System Based on MCDM}

In this study, the combination of fuzzy theory with AHP method has determined priority factors that can affect the selection of BAPV system design for campus areas. To support the work and result of fuzzy AHP algorithm, the classic AHP method is also used in this study. The priority weights of criteria, subcriteria, and alternatives have been obtained using both algorithms. Both of these algorithms show the same priority rank that shows in Figure 9. Figure 9 shows technical factor is the most important priority for choosing a BAPV system design. Both algorithms show the priority rank from perspective of criteria as follows: technical > economic $>$ environment $>$ sizing system.

Tables 5 and 6 show more detail about the assessment of five BAPV system designs from several perspectives that proves if each design has a different point of excellence. As example, alternative design 1 with HIT PV has an advantage in "total weight PV" (represented as design 1). Although the amount of PV used in alternative design 1 is less than alternative design 2, HIT PV is lighter than CdTe PV (represented as design 2). Alternative design 3 with CIS PV has the lowest PV unit price. But, this does not make it has the cheapest LCC. Alternative design 5 with polycrystalline $\mathrm{PV}$ has same amount of PV used with alternative design 1 but has worse performance. However, the advantages and disadvantages of each design need to be prioritized diligently.

The results of priority weights subcriteria with both algorithms are shown in Figure 10. Rank of priority weights in the sizing system criteria is as follows: type of PV $>$ amount of $\mathrm{PV}>$ price of $\mathrm{PV}>$ covered area by $\mathrm{PV}>$ weight of $\mathrm{PV}$. The rank of priority weights in technical factor criteria is as follows: performance ratio $>$ energy spent to load $>$ total 


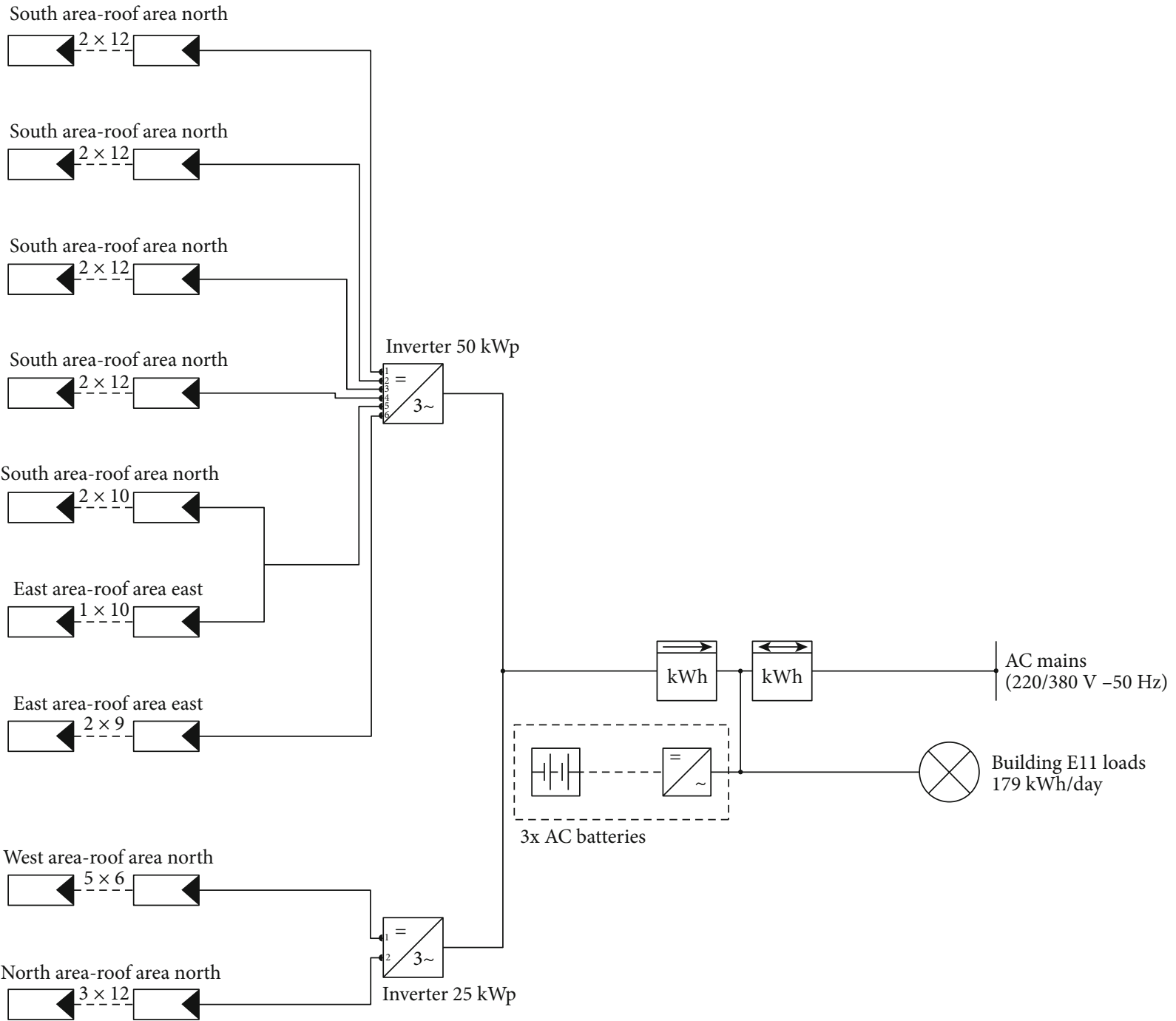

FIGURE 12: Schematic design of BAPV system connected to grid and BESS for E11 Building.

energy in lifetime $>$ grid feed-in. The rank of priority weights in economic factor criteria is as follows: cost of energy $>$ life cycle cost.

Reviewing the priority weight of criteria and subcriteria in Figures 9 and 10, the priority weight values of both algorithms are very different but give the same priority rank. This may cause triangular fuzzy numbers involving numbers upper, middle, lower, and classic AHP only depends on a single number scale. Fuzzy AHP spreads the weight of values more convergence on each element. Different with classic AHP has a significant value of weight in each criteria and subcriteria. But, both algorithms still show the same priority rank diligently.

The final stage is determining the priority weights of each alternative BAPV system design. The priority weight of alternative BAPV system design is calculated by adding up the normalized weights from the multiplication of priority weights from criteria and subcriteria. Priority weight of alternative design BAPV systems using fuzzy AHP and classic AHP is shown in Figure 11. Based on fuzzy AHP and classic AHP, alternative design 4 has the biggest priority weight than other designs for both BAPV system scenarios. Then, alternative design 2 can be the second option, and the alternative design 5 is the worst option for both scenarios.

Alternative design 4 of a BAPV system with monocrystalline PV (represented as design 4) is the most feasible option to be implemented at case study location with many advantages. Considering the efficiency of each PV module, the mSi PV has the highest efficiency than the others, which is 20.6\%. Considering the temperature coefficient of each PV module, $\mathrm{m}-\mathrm{Si} \mathrm{PV}$ with temperature coefficient of $-0.25 \% /{ }^{\circ} \mathrm{C}$ has the best performance than others. Then polycrystalline PV (represented as design 5) with the higher temperature coefficient of $-0.40 \% /{ }^{\circ} \mathrm{C}$ has the lowest system performance. This is because the BAPV system was designed in tropical country with dominant hot weather. It proves PV modules with low-temperature coefficients have better performance than PV modules with high-temperature coefficients.

Another advantage of BAPV system design with $\mathrm{m}-\mathrm{Si}$ is having the lowest life cycle cost even though the monocrystalline has not the lowest module unit price. The lowest life cycle cost with the best system performance makes the 


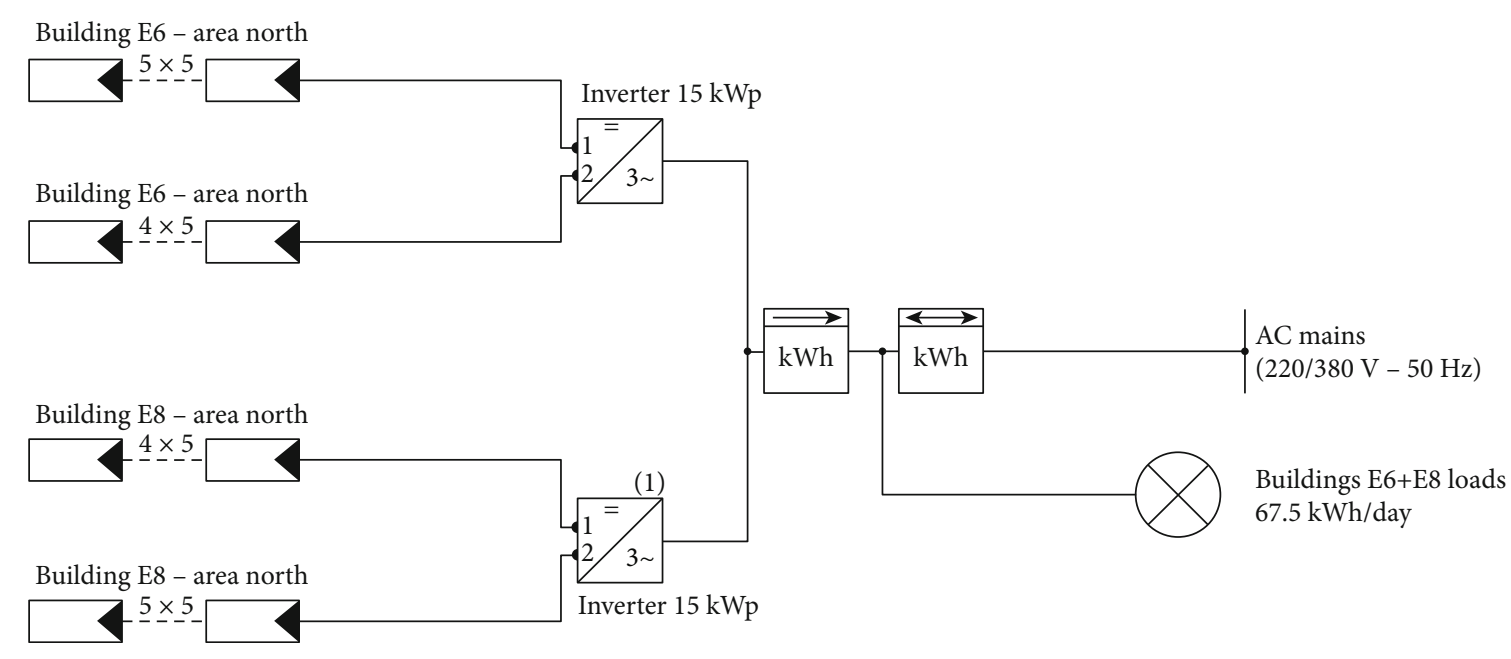

FIgURE 13: Schematic design of BAPV system connected to the grid for E6+E8 Buildings.

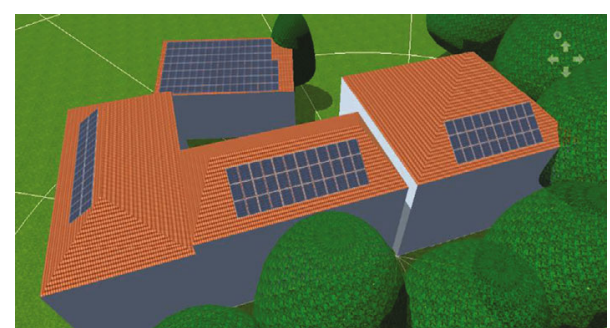

FIGURE 14: Architectural from top view at project site (BAPV system design for E11 Building).

lowest cost of energy compared to other system designs. Therefore, monocrystalline is feasible to be implemented in case studies.

5.1. Detail of Selected BAPV System Design. The design 4 alternative in this study uses monocrystalline PV type. BAPV system design for E11 Building (scenario 1) requires $210 \mathrm{PV}$ modules with nominal rating $350 \mathrm{WP}$. BAPV system design for E6+E8 Buildings (scenario 2) requires $90 \mathrm{PV}$ modules with the same series and nominal rating PV. Detail configuration of array and string is shown in Figures 12 and 13. The output of PV array was connected with 3-phase inverter from inverter S. Inverters are used for interconnecting with the grid and battery through a utility meter. In this project site, BAPV system operated in $50 \mathrm{~Hz}$ of frequency and $380 \mathrm{~V}$ of line-to-line voltage. The layout design of the PV module is planned as carefully as possible in order to minimize the shading factor of trees or buildings around the building. The array and string lines are arranged, so there is no shadow between the array and string. Architecture and placement of PV from the second alternative design BAPV system are shown in Figures 14 and 15.

\section{Conclusions}

A comprehensive evaluation of PV technology priority in the BAPV system design has been carried out based on a combi-

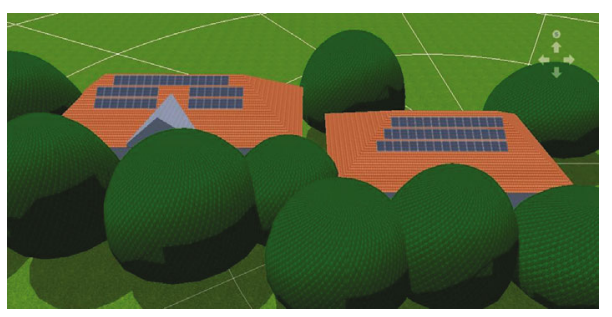

Figure 15: Architectural from top view at the project site (BAPV system design for E6+E8 Buildings).

nation of fuzzy theory and AHP as an optimization technique. The optimization technique is used to find a suitable and optimal BAPV system design based on technoeconomic assessment. Evaluation is considered several perspectives such as system sizing, technical, economic, and environmental. Based on these perspectives, fuzzy AHP and classic AHP analyze the priority rankings of expert opinion as follows: technical $>$ economic $>$ environment $>$ sizing system. This research has analyzed five BAPV system designs that were experimented in campus areas in tropical countries. The PV design is constructed with five existing PV technologies such as $\mathrm{m}-\mathrm{Si}$, p-Si, CdTe, CIS, and HIT. Based on both algorithms with considering the criteria and subcriteria, design of the BAPV system using monocrystalline (represented as alternative design 4) became the most optimal design. The second option is design of BAPV system using CdTe PV (represented as alternative design 2) for all scenario in project site. Scenario design of BAPV system connected to the grid and battery consists of $210 \mathrm{~m}$-Si PV modules and 3 batteries with output energy system in lifetime is 2,508.66 MWh/25 years and cost of energy is $\$ 0.105$ (E11 Building). Scenario design of BAPV system connected to the grid without battery consists of $90 \mathrm{~m}-\mathrm{Si}$ PV modules with output energy system in lifetime is 1,055.4 MWh/25 years and cost of energy is \$0.093 (E6 and E8 Buildings).

\section{Data Availability}

The data used to support the findings of this study are available from the first author and corresponding author upon request. 


\section{Conflicts of Interest}

The authors declare that they have no conflict of interest with regard to publishing this article.

\section{Acknowledgments}

This work is partly supported by the Lembaga Penelitian dan Pengabdian Masyarakat UNNES under grant no. 71.13.5/UN37/PPK.3.1/2019 and previous grant funding and then the team of Smart Energy Project Study (UEESRG), Department of Electrical Engineering, Universitas Negeri Semarang.

\section{References}

[1] B. Dudley, 67 th Edition BP Statistical Review of World Wide Energy, BP.com, London, UK, 2018.

[2] N. Uddin, M. M. Rashid, M. G. Mostafa, H. Belayet, S. M. Salam, and N. A. Nithe, "Global energy: need, present status, future trend and key issues," Global Journal of Research In Engineering, vol. 16, no. 1, 2016.

[3] K. S. Khan, Z. Ullah, B. Khan, I. Sami, S. M. Ali, and C. A. Mehmood, "Assessment of hybrid off-grid wind photovoltaic system: a case study of university campus," in 2017 International Conference on Energy Conservation and Efficiency (ICECE), pp. 16-21, Lahore, Pakistan, 22-23 Nov. 2017.

[4] Subiyanto, A. Mohamed, and M. A. Hannan, "Intelligent photovoltaic maximum power point tracking controller for energy enhancement in renewable energy system," Journal of Renewable Energy, vol. 2013, Article ID 901962, 9 pages, 2013.

[5] A. Jäger-Waldau, "Snapshot of photovoltaics-March 2017," Sustainability, vol. 9, no. 5, p. 783, 2017.

[6] Y. Hongxing and L. Yutong, "Potential of building-integrated photovoltaic applications," International Journal of LowCarbon Technologies, vol. 2, no. 3, pp. 250-261, 2007.

[7] G. Aaditya, R. R. Rao, and M. Mani, "Integrability comparison between BIPV and BAPV in tropical conditions: a Bangalore case - study," in 2017 IEEE 44th Photovoltaic Specialist Conference (PVSC), pp. 604-607, Washington, DC, USA, 25-30 June 2017.

[8] N. M. Kumar, K. Sudhakar, and M. Samykano, "Performance comparison of BAPV and BIPV systems with c-Si, CIS and CdTe photovoltaic technologies under tropical weather conditions," Case Studies in Thermal Engineering, vol. 13, p. 100374, 2019.

[9] Centre for Green Energy Technology, Pondicherry University, S. Barua, R. A. Prasath, and D. Boruah, "Rooftop solar photovoltaic system design and assessment for the academic campus using PVsyst software," International Journal of Electronics and Electrical Engineering, vol. 5, no. 1, pp. 76-83, 2017.

[10] A. Raj, M. Gupta, and S. Panda, "Design simulation and performance assessment of yield and loss forecasting for 100 KWp grid connected solar PV system," in International Conference on Next Generation Computing Technologies, Dehradun, India, 14-16 Oct. 2016.

[11] A. S. Baitule, K. Sudhakar, and E. Centre, "Solar powered green campus: a simulation study," International Journal of LowCarbon Technologies, vol. 12, no. 4, pp. 400-410, 2017.

[12] S. Nag, S. Kundu, D. Sinha, S. Roychowdhury, and P. Mukherjee, "A comparative-techno economic feasibility study between roof-top and building integrated photovoltaic technology for development of green campus," in 2016 IEEE 7th Annual Ubiquitous Computing, Electronics \& Mobile Communication Conference (UEMCON), New York, NY, USA, 20-22 Oct. 2016.

[13] Y. Wang, M. Li, R. H. E. Hassanien, X. Ma, and G. Li, "GridConnected Semitransparent Building-Integrated Photovoltaic System: The Comprehensive Case Study of the $120 \mathrm{kWp}$ Plant in Kunming, China," International Journal of Photoenergy, vol. 2018, Article ID 6510487, 13 pages, 2018.

[14] M. I. Al-najideen and S. S. Alrwashdeh, "Design of a solar photovoltaic system to cover the electricity demand for the faculty of Engineering- Mu'tah University in Jordan," ResourceEfficient Technologies, vol. 3, no. 4, pp. 440-445, 2017.

[15] C. Li, "Comparative performance analysis of grid-connected PV power systems with different PV technologies in the hot summer and cold winter zone," International Journal of Photoenergy, vol. 2018, Article ID 8307563, 9 pages, 2018.

[16] A. K. Shukla, K. Sudhakar, and P. Baredar, "Simulation and performance analysis of $110 \mathrm{~kW}_{\mathrm{p}}$ grid- connected photovoltaic system for residential building in India: a comparative analysis of various PV technology," Energy Reports, vol. 2, pp. 82-88, 2016.

[17] J. Y. Ye, T. Reindl, A. G. Aberle, and T. M. Walsh, "Performance degradation of various $\mathrm{PV}$ module technologies in tropical Singapore," IEEE Journal of Photovoltaics, vol. 4, no. 5, pp. 1288-1294, 2014.

[18] C. Li, D. Zhou, and Y. Zheng, "Techno-economic comparative study of grid-connected PV power systems in five climate zones, China," Energy, vol. 165, pp. 1352-1369, 2018.

[19] S. M. Hashim, "An economic evaluation of grid connected photovoltaic system for a residential house in Khartoum," in International Conference on Computer, Control, Electrical, and Electronics Engineering (ICCCEEE), pp. 1-6, Khartoum, Sudan, 12-14 Aug. 2018.

[20] F. Balo and L. Sagbansua, "A multi-criterion analysis for choosing photovoltaic panel," International Journal of Engineering, vol. 2, no. 4, 2016.

[21] M. Azizkhani, A. Vakili, Y. Noorollahi, and F. Naseri, "Potential survey of photovoltaic power plants using analytical hierarchy process (AHP) method in Iran," Renewable and Sustainable Energy Reviews, vol. 75, pp. 1198-1206, 2017.

[22] A. Kengpol, P. Rontlaong, and M. Tuominen, "A decision support system for selection of solar power plant locations by applying fuzzy AHP and TOPSIS: an empirical study," Journal of Software Engineering and Applications, vol. 06, no. 09, pp. $470-481,2013$.

[23] B. Azzopardi, J. Mutale, and E. A. Martínez-Ceseña, “Decision support system for ranking photovoltaic technologies," IET Renewable Power Generation, vol. 7, no. 6, pp. 669-679, 2013.

[24] M. Ebrahimi, M. Aramesh, and Y. Khanjari, "Innovative ANP model to prioritization of PV/T systems based on cost and efficiency approaches: with a case study for Asia," Renewable Energy, vol. 117, pp. 434-446, 2018.

[25] TeknikElektro UNNES, https:/goo.gl/maps/MJrQTqUJzLpfQigTA.

[26] Procurement Service Unit UNNES, Building Construction Data, UNNES, 2015.

[27] A. C. Pradita, Energy Audit for Achieving the Efficiency of Use of Electric Power in the Faculty of Engineering, Semarang State University, Thesis of Electrical Engineering Department, Universitas Negeri Semarang, 2018. 
[28] J. Koskela, A. Rautiainen, and P. Järventausta, "Using electrical energy storage in residential buildings - sizing of battery and photovoltaic panels based on electricity cost optimization," Applied Energy, vol. 239, pp. 1175-1189, 2019.

[29] E. Tarigan, "Simulation and feasibility studies of rooftop PV system for university campus buildings in Surabaya, Indonesia," International Journal of Renewable Energy Research, vol. 8, no. 2, pp. 895-908, 2018.

[30] S. M. Saad, N. Kunhu, and A. M. Mohamed, "A fuzzy-AHP multi-criteria decision-making model for procurement process," International Journal of Logistics Systems and Management, vol. 23, no. 1, pp. 1-24, 2016.

[31] G. Y. Palacios-Jaimes, P. Martín-Ramos, F. J. Rey-Martínez, and I. A. Fernández-Coppel, "Transformation of a university lecture hall in Valladolid (Spain) into a NZEB: LCA of a BIPV system integrated in its façade," International Journal of Photoenergy, vol. 2017, Article ID 2478761, 11 pages, 2017.

[32] R. Sharma, "Grid connected solar PV system design and calculation by using $\mathrm{PV} * \mathrm{SOL}$ premium simulation tool for campus hostels of RTU Kota," in International Conference on circuits Power and Computing Technologies, pp. 1-5, Kollam, India, 20-21 April 2017.

[33] C. O. Okoye and B. C. Oranekwu-Okoye, "Economic feasibility of solar PV system for rural electrification in Sub-Sahara Africa," Renewable and Sustainable Energy Reviews, vol. 82, pp. 2537-2547, 2018.

[34] FedEx, "FedEx shipping tariff," 2019, https://www.fedex.com/ en-id/shipping/rates.html.

[35] S. K. Sakiliba, A. S. Hassan, J. Wu, E. S. Sanneh, and S. Ademi, "Assessment of stand-alone residential solar photovoltaic application in Sub-Saharan Africa: a case study of Gambia," International Journal of Photoenergy, vol. 2015, Article ID 640327, 10 pages, 2015.

[36] K. Hasim and M. K. Almsafir, "An economic evaluation of grid-connected photovoltaic generation system for residential house in Malaysia," Journal of Advanced Science and Engineering Research, vol. 4, no. 1, pp. 47-60, 2014.

[37] S. Rehman, M. A. Bader, and S. A. Al-Moallem, "Cost of solar energy generated using PV panels," Renewable and Sustainable Energy Reviews, vol. 11, pp. 1843-1857, 2007.

[38] B. Indonesia, "BI 7-day (reverse) repo rate," 2018, https:// www.bi.go.id/id/moneter/bi-7day-RR/penjelasan/Contents/ Default.aspx.

[39] A. Allouhi, R. Saadani, T. Kousksou, R. Saidur, A. Jamil, and M. Rahmoune, "Grid-connected PV systems installed on institutional buildings: technology comparison, energy analysis and economic performance," Energy and Buildings, vol. 130, pp. 188-201, 2016.

[40] I. Jamil, J. Zhao, L. Zhang, S. F. Rafique, and R. Jamil, "Uncertainty analysis of energy production for a $3 \times 50 \mathrm{MW}$ AC photovoltaic project based on solar resources," International Journal of Photoenergy, vol. 2019, Article ID 1056735, 12 pages, 2019.

[41] J. Ooi, M. A. B. Promentilla, R. R. Tan, D. K. S. Ng, and N. G. Chemmangattuvalappil, "Integration of fuzzy analytic hierarchy process into multi-objective computer aided molecular design," Computers \& Chemical Engineering, vol. 109, pp. 191-202, 2018.

[42] P. Kaur, "Selection of vendor based on intuitionistic fuzzy analytical hierarchy process," Advances in Operations Research, vol. 2014, Article ID 987690, 10 pages, 2014.
[43] M. S. D. Putra, S. Andryana, and A. G. Fauziah, "Fuzzy analytical hierarchy process method to determine the quality of gemstones," Advances in Fuzzy Systems, vol. 2018, Article ID 9094380, 6 pages, 2018.

[44] D. Y. Chang, "Applications of the extent analysis method on fuzzy AHP," European Journal of Operational Research, vol. 95, no. 3, pp. 649-655, 1996. 

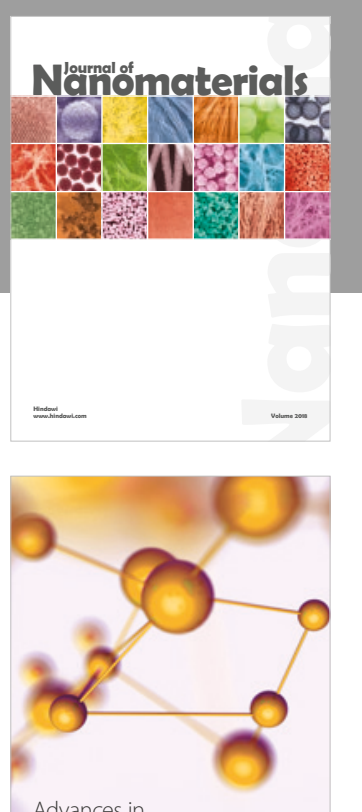

Physical Chemistry
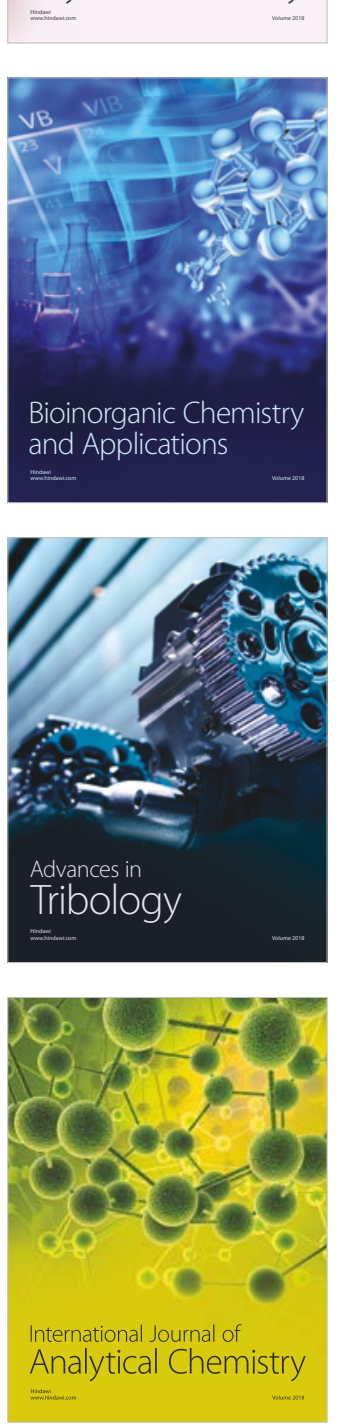

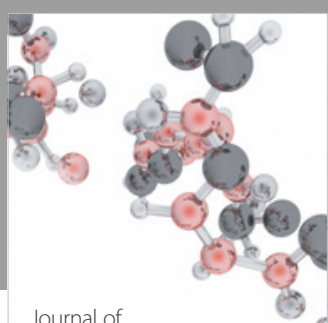

Analytical Methods

in Chemistry

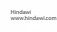

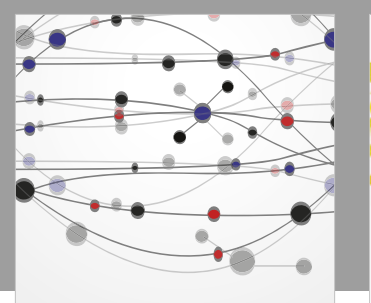

The Scientific World Journal

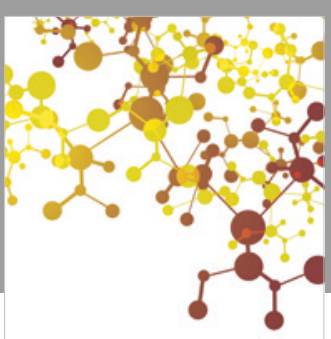

Journal of

Applied Chemistry
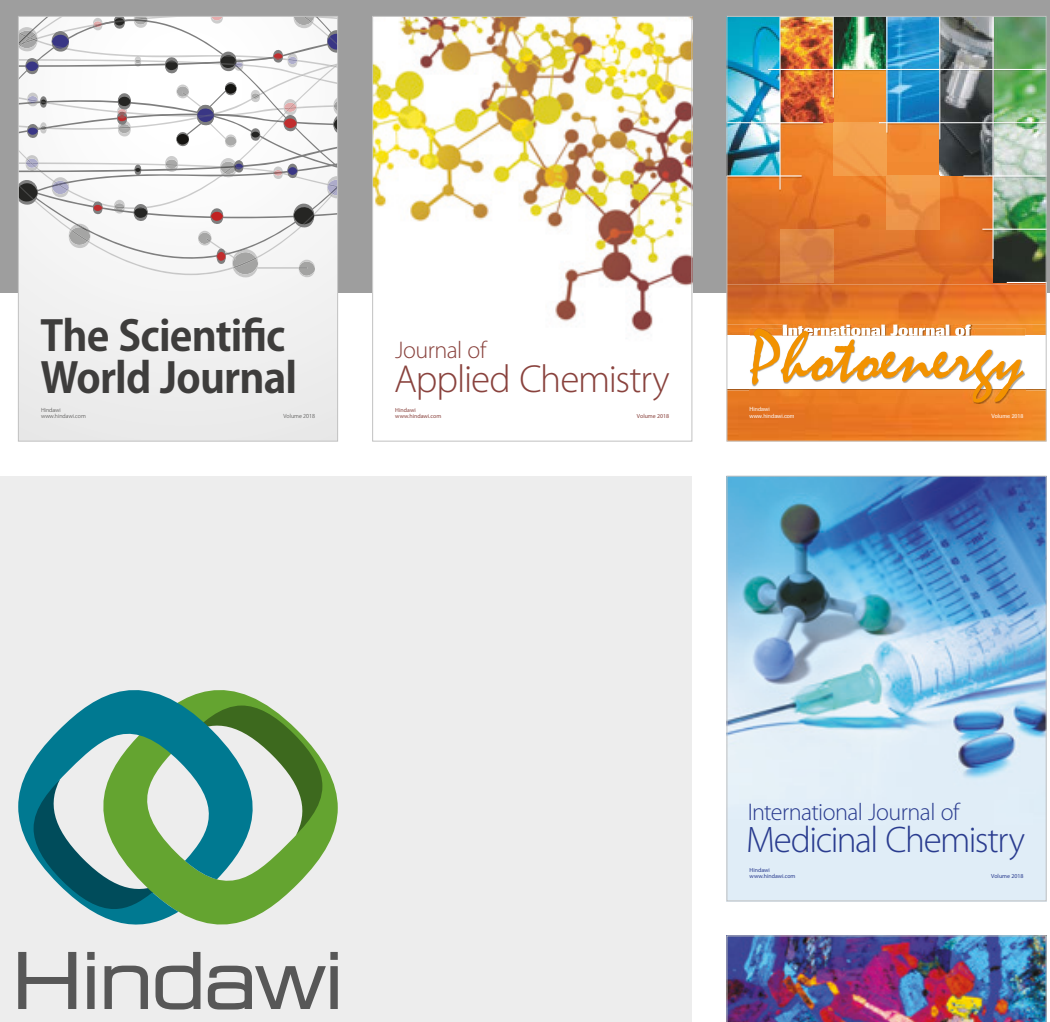

Submit your manuscripts at

www.hindawi.com
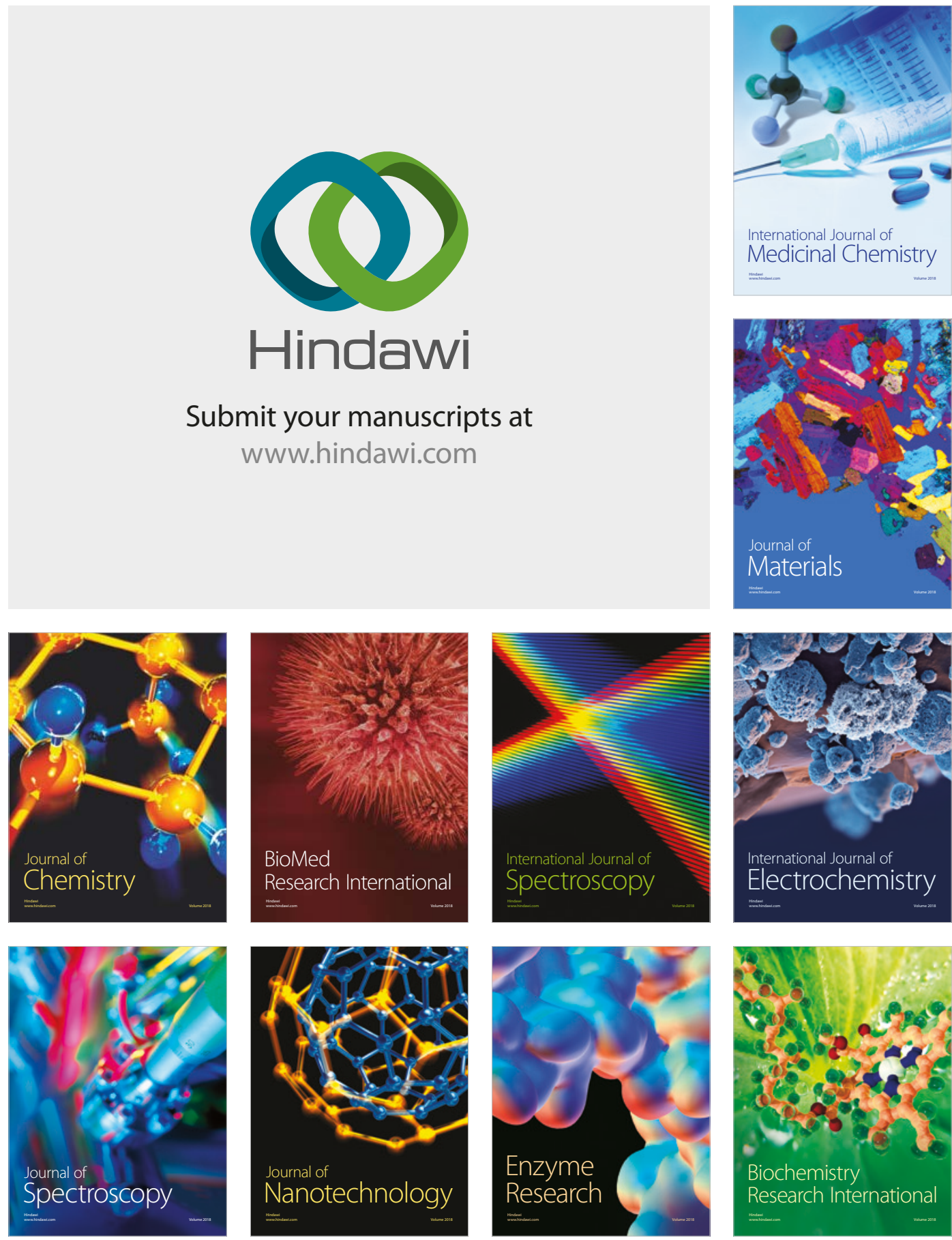
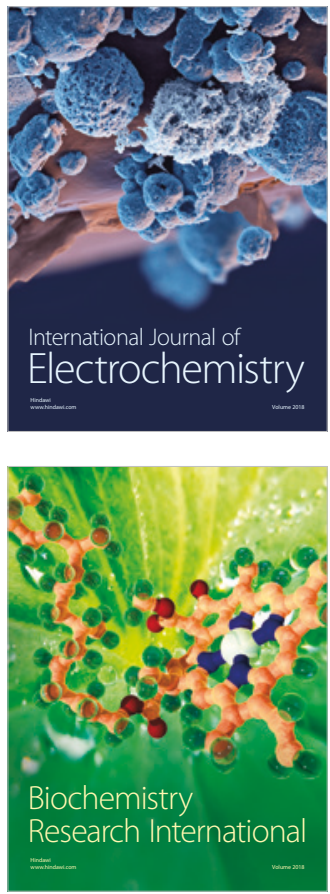